\title{
PELAKSANAAN VAKSINASI COVID-19 DI INDONESIA: HAK ATAU KEWAJIBAN WARGA NEGARA
}

\author{
Fridolin Dapa Dadu, Muhammad Ali Sodik \\ INSTITUT ILMU KESEHATAN STRADA INDONESIA \\ fridolindapadadu@gmail.com, alisodik2012@gmail.com
}

\begin{abstract}
ABSTRAK
Pandemi Covid-19 menimbulkan status kedaruratan di Indonesia. Melalui Keputusan Presiden Nomor 11 Tahun 2020, Indonesia telah mengumumkan status kedaruratan kesehatan. Berbagai upaya dilakukan dalam rangka mengatasi dampak pandemi Covid19. Salah satunya adalah upaya vaksinasi. Namun, di masyarakat timbul pro kontra terkait vaksinasi tersebut. Sejumlah kalangan masyarakat menolak untuk divaksin. Oleh sebab itu, artikel ini akan menjelaskan apakah vaksinasi merupakan hak atau kewajiban bagi masyarakat dan apakah penolak vaksin dapat dikenakan sanksi pidana. Penelitian ini adalah penelitian hukum dengan tipe doctrinal research serta menggunakan pendekatan konseptual dan pendekatan peraturan perundang-undangan. Hasil penelitian menunjukkan bahwa vaksinasi yang pada mulanya adalah hak setiap orang, dapat menjadi suatu kewajiban mengingat situasi kedaruratan di Indonesia saat ini. Hal ini karena seseorang yang tidak divaksin berpotensi untuk menularkan bahkan membunuh orang lain. Adapun mengenai pemidanaan, hal tersebut seyogyanya menjadi ultimum remedium, apabila pranata-pranata lainnya seperti metode persuasif, sosialisasi bahkan sanksi administrasi terkait vaksinasi sudah tidak dapat berfungsi sedangkan kondisi kedaruratan kesehatan di Indonesia semakin memburuk.
\end{abstract}

Kata Kunci: vaksinasi, hak asasi, warga negara, tanggung jawab, sanksi pidana

\section{Latar Belakang}

Wabah Corona Virus Disease 2019 atau disebut sebagai Covid-19 yang melanda dunia pada tahun 2020 menimbulkan kedaruratan di berbagai negara, salah satunya adalah Indonesia. Presiden Joko Widodo melalui Keputusan Presiden Nomor 11 Tahun 2020 tentang Penetapan Kedaruratan Kesehatan Masyarakat Corona Virus Disease 2019 (Covid-19), menetapkan status kedaruratan kesehatan, yang juga diikuti dengan terbitnya Peraturan Pemerintah Pengganti Undang- Undang Nomor 1 Tahun 2020 tentang Kebijakan Keuangan Negara dan Stabilitas Sistem Keuangan Untuk Penanganan Pandemi Corona Virus Disease 2019 (COVID- 19) dan/ atau dalam Rangka Menghadapi Ancaman Yang Membahayakan Perekonomian Nasional dan/atau Stabilitas Sistem Keuangan ${ }^{2}$ dan Peraturan Pemerintah Nomor 21 Tahun 
2020 tentang Pembatasan Sosial Berskala Besar Dalam Rangka Percepatan Penanganan Corona Virus Disease 2019 (Covid-19. Pandemi Covid-19 yang melanda seluruh negara di dunia mengubah tatanan kehidupan manusia. Umat manusia dipaksa untuk beradaptasi dengan kebiasaan baru. Di Indonesia, kebiasaan-kebiasaan baru tersebut tercermin di antaranya dengan adanya 'Pesan Ibu' yang berisikan kewajiban 3M (memakai masker, menjaga jarak dan mencuci tangan dengan sabun) bagi masyarakat serta $3 \mathrm{~T}$ (testing, tracing, treatment) bagi Pemerintah. ${ }^{4}$ Pada perkembangan penanganan Covid-19 diberbagaidunia, terdapatsejumlahpenelitian dalam rangka pembuatan vaksin maupun obat untuk mengatasi Covid-19. Khusus berkaitan dengan vaksin, terdapat sejumlah merek vaksin untuk Covid-19 yang telah dibuat. Indonesia menggunakan sejumlah merek vaksin dalam rangka penanganan Covid-19 di Indonesia. Rinciannya adalah 3 juta dosis yang sudah tiba di Tanah Air (per 6 Januari 2021) ditambah 122,5 juta dosis lagi dari Sinovac, kemudian dari Novavax sebanyak itu 50 juta dosis, dari COVAX/Gavi sejumlah 54 juta dosis, dari AstraZeneca 50 juta dosis dan dari Pfizer sejumlah 50 juta dosis vaksin. Total vaksin yang dipesan adalah 329,5 Juta Dosis Vaksin Covid-19.

Pemerintah melalui Menteri Kesehatan menyatakan bahwa telah mendistribusikan 1,2 juta dosis vaksin Covid-19 ke 34 (tiga puluh empat) provinsi di seluruh Indonesia per 7 Januari 2021. Sedangkan pelaksanaan vaksinasi direncanakan akan dilakukan pada minggu kedua Januari 2021, setelah dikeluarkannya izin penggunaan darurat atau Emergency Use Authorization oleh BPOM (Badan Pengawas Obat dan Makanan).

Selain itumasyarakat juga mempertanyakan efikasi dan efektivitas dari vaksin Covid-19 tersebut dengan dalih seperti tidak efektif, isu konspirasi, menimbulkan efek samping termasuk aspek kehalalannya (walaupun berkaitan dengan aspek kehalalannya telah dinyatakan suci dan halal oleh Majelis Ulama Indonesia (MUI).

Bahkan terdapat daerah yang menyatakan bahwa masyarakat yang menolak vaksin Covid-19 akan dikenakan denda. Sebagai contoh di DKI Jakarta, yang mana pada Peraturan Daerah Provinsi Daerah Khusus Ibukota Jakarta Nomor 2 Tahun 2020 tentang Penanggulangan Covid-19 DKI Jakarta yang menyebutkan bahwa setiap orang yang dengan sengaja menolak untuk dilakukan pengobatan dan/atau vaksinasi Covid-19 dapat dipidana dengan denda paling banyak sebesar Rp5.000.000.

Akibatnya, sejumlah pihak yang kontra menyatakan bahwa pasal pada Perda tersebut bertentangan dengan Undang-Undang maupun hak atas kesehatan yang tertuang dalam Undang-Undang Dasar Negara Indonesia Tahun 1945. Sedangkan pihak yang pro menyatakan pasal tersebut secara khusus maupun adanya pelaksanaan vaksinasi di Indonesia secara umum adalah bertujuan untuk menyelamatkan masyarakat dari wabah Covid-19. 


\section{Kasus atau Masalah}

Berdasarkan latar belakang tersebut di atas maka dalam artikel ini akan dibahas mengenai: apakah vaksinasi Covid-19 merupakan hak ataukah kewajiban bagi masyarakat, serta bagaimana pemidanaan terhadap penolak vaksin Covid-19 ditinjau dari norma hukum di Indonesia?

\section{Tinjauan Pustaka}

Hak Asasi Manusia menyampaikan bahwa vaksinasi Covid-19 merupakan bagian dari kewajiban seluruh warga negara untuk mewujudkan kesehatan masyarakat. Namun sejumlah aktivis pada bidang Hak Asasi Manusia tegas menyatakan bahwa menolak vaksin adalah hak asasi rakyat.

\section{Pembahasan}

Kesehatan adalah keadaan sehat, baik secara fisik, mental, spritual maupun sosial yang memungkinkan setiap orang untuk hidup produktif secara sosial dan ekonomis. (Pasal 1 angka 1 Undang-Undang Nomor 36 Tahun 2009 tentang Kesehatan ${ }^{12}$ ), karena itu kesehatan merupakan dasar dari diakuinya derajat kemanusiaan. Tanpa kesehatan, seseorang menjadi tidak sederajat secara kondisional. Tanpa kesehatan, seseorang tidak akan mampu memperoleh hak-hak lainnya. Sehingga kesehatan menjadi salah satu ukuran selain tingkat pendidikan dan ekonomi, yang menentukan mutu dari sumber daya manusia (Human Development Index).

Hak atas kesehatan sebagai hak asasi manusia telah diakui dan diatur dalam berbagai instrumen internasional. Jaminan pengakuan hak atas kesehatan.

Indonesia merupakan negara yang memberikan pelindungan secara konstitusional terhadap Hak Asasi Manusia (HAM). Pelindungan terhadap HAM tersebut dimasyarakatkan secara luas dalam rangka mempromosikan penghormatan dan pelindungan terhadap hak-hak asasi manusia sebagai ciri yang penting suatu negara hukum yang demokratis. Setiap manusia sejak kelahirannya menyandang hak-hak dan kewajiban-kewajiban yang bersifat bebas dan asasi. Terbentuknya negara dan demikian pula penyelenggaraan kekuasaan suatu negara tidak boleh mengurangi arti atau makna kebebasan dan hak-hak asasi kemanusiaan itu. Karena itu, adanya pelindungan dan penghormatan terhadap hak-hak asasi manusia merupakan pilar yang sangat penting dalam setiap negara yang disebut sebagai negara hukum. Jika dalam suatu negara, hak asasi manusia terabaikan atau dilanggar dengan sengaja dan penderitaan yang ditimbulkannya tidak dapat diatasi secara adil, maka negara yang bersangkutan tidak dapat disebut sebagai 
negara hukum dalam arti yang sesungguhnya.

Berkaitan dengan pelindungan konstitusional terhadap hak atas kesehatan mental tercermin dalam Pasal $28 \mathrm{H}$ ayat (1) Undang-Undang Dasar Negara Republik Indonesia Tahun 1945 yang menyatakan bahwa "Setiap orang berhak hidup sejahtera lahir dan batin, bertempat tinggal dan mendapatkan lingkungan hidup yang baik dan sehat serta berhak memperoleh pelayanan kesehatan".

Bahkan, lebih lanjut disebutkan juga mengenai kewajiban negara terkait hal tersebut dalam Pasal 34 ayat (3) yang menyatakan bahwa "Negara bertanggung jawab atas penyediaan fasilitas pelayanan kesehatan dan fasilitas pelayanan umum yang layak." Hal ini menunjukkan bahwa hak atas kesehatan termasuk di dalamnya kesehatan mental dilindungi secara konstitusional.

Disebutkannya konsep mengenai hak asasi yang berkaitan dengan kesehatan tersebut, maka negara mempunyai kewajiban untuk memenuhi hak tersebut.

Berkaitan dengan penanganan pandemi Covid-19 di Indonesia, Pemerintah telah mengambil langkah-langkah dalam rangka melindungi kesehatan warga negara. Mulai dari menetapkan status darurat kesehatan melalui Keputusan Presiden Nomor 11 Tahun 2020 tentang Penetapan Kedaruratan Kesehatan Masyarakat Corona Virus Disease 2019 (Covid-19), melaksanakan kewajiban Pemerintah dalam rangka melaksanakan 3T (testing, tracing, treatment), membangun rumah sakit darurat bahkan hingga melakukan pembatasan pada berbagai wilayah sebagaimana yang tertuang dalam Peraturan Pemerintah Nomor 21 Tahun 2020 tentang Pembatasan Sosial Berskala Besar Dalam Rangka Percepatan Penanganan Corona Virus Disease 2019 (Covid-19).

Salah satu upaya lain yang tengah dilakukan Pemerintah dalam rangka melindungi kesehatan warga negara Indonesia adalah pelaksanaan vaksinasi yang telah dimulai pada tanggal 13 Januari 2021 dengan penerima vaksin pertama adalah Presiden Republik Indonesia, Joko Widodo.Di tingkat masyarakat, terjadi pro dan kontra terkait pelaksanaan vaksinasi di Indonesia. Salah satu isu hukum berkaitan dengan vaksinasi ini adalah apakah vaksinasi untuk masyarakat merupakan hak ataukah kewajiban. Sebagaimana yang disebutkan pada bagian pendahuluan bahwa sejumlah aktivis tegas menyatakan bahwa menolak vaksin adalah hak asasi rakyat. Mereka menggunakan dasar hukum Pasal 5 ayat (3) Undang-Undang Nomor 36 Tahun 2009 tentang Kesehatan yang menyatakan bahwa "Setiap orang berhak secara mandiri dan bertanggung jawab menentukan sendiri pelayanan kesehatan yang diperlukan bagi dirinya."

Sekilas, alasan hukum tersebut dapat menjadi legitimasi terhadap penolakan vaksin Covid-19 berdasarkan hukum di Indonesia. Namun bila dikaji berdasarkan kondisi bernegara Indonesia di masa pandemi Covid-19, pelaksanaan vaksinasi dapat menjadi suatu hal yang bersifat wajib. 


\section{Kesimpulan}

Berdasarkan pembahasan di atas, maka dapat disimpulkan bahwa vaksinasi dalam rangka penanganan Covid-19 adalah suatu hak sekaligus kewajiban dari warga negara. Memang, terdapat hak seseorang untuk memilih pelayanan kesehatan baginya. Namun bila dilihat pada konteks virus Covid-19 yang berskala pandemi, serta merujuk pada poin kedua bahwa seseorang yang tidak divaksin justru dapat berpotensi menjadi virus carrier bagi orang lain, maka hak tersebut dapat dikurangi dalam rangka untuk mencapai tujuan negara yakni melindungi segenap bangsa Indonesia dan seluruh tumpah darah Indonesia (dalam hal ini, melindungi dari virus Covid-19), dan juga termasuk melindungi hak asasi seseorang itu sendiri dalam rangka memperoleh hak untuk hidup secara sehat. Oleh sebab itu, vaksinasi yang pada mulanya adalah suatu hak bagi seseorang dapat berubah menjadi suatu kewajiban mengingat negara dalam keadaan darurat dan selanjutnya adalah berkaitan dengan kewajiban asasi manusia untuk menghargai hak asasi orang lain, dalam hal ini adalah hak atas kesehatan orang lain.

Adapun terkait sanksi pidana dalam pemberlakuan kewajiban vaksinasi, seyogianya tetap menjadi suatu sarana terakhir (ultimum remedium) apabila pranata pranata-pranata lainnya tidak berfungsi. Namun, melihat situasi kondisi di Indonesia semakin memburuk akibat Covid-19, sehingga dimungkinkan untuk menyelematkan Indonesia beserta segenap unsurnya dari kondisi yang kian memburuk tersebut, dengan penerapan sanksi pidana dapat diberlakukan.

\section{DAFTAR PUSTAKA}

BUKU :

Anggriani, Jum., Hukum Administrasi Negara,

(Jakarta: Graha IImu , 2012).

Asshiddiqie, Jimly. Konstitusi dan Konstitusionalisme Indonesia. (Jakarta: Sinar Grafika, 2011).

Atmadja, I Dewa Gede. Hukum Konstitusi, Problematika Konstitusi Indonesia Sesudah Perubahan UUD 1945,(Malang: Setara Press, 2010).

Budiardjo, Miriam., Dasar-Dasar IImu Politik, 
(Jakarta: PT. Gramedia, 1991).

Campbell, Henry Black., Black's Law Dictionary, St. Paul Minn : $4^{\text {th }}$ Edition, West Publishing CO, 1968).

Hadjon, Philipus M. Perlindungan Hukum Bagi Rakyat Indonesia, (Surabaya: Peradaban, 2017).

Heywood, Andrew. Politic, (London: Fourth Edition, Palgrave Macmillan, 2013).

HR, Ridwan., Hukum Administrasi Negara,

(Jakarta: PT RajaGrafindo Persada, 2016).

Hutchinson, Terry C. Developing legal research skills : expanding the paradigm, (Melbourne : Melbourne University Law Review, 2008).

Komite Penanganan Covid-19 dan Pemulihan Ekonomi Nasional, Paket Advokasi, Vaksinasi Covid-19, Lindungi Diri, Lindungi Negeri, (Jakarta: KPCPEN , Januari 2021).

Kusnardi, Moh. dan Bintan R. Saragih, Ilmu Negara, (Jakarta: Gaya Media Pratama, 2000). Mahfud MD, Moh., Konstitusi dan Hukum dalam Kontroversi Isu, (Jakarta: Rajawali Pers, 2010).

Mahfud MD, Moh., Membangun Politik Hukum, Menegakkan Konstitusi, (Jakarta: LP3ES, 2006).

Maroni, Pengantar Hukum Pidana Administrasi, (Bandar Lampung: CV. Anugrah Utama Raharja, 2015).

Marzuki, Peter Mahmud. Penelitian Hukum, (Jakarta: Kencana Prenadanamedia Group, 2017).

JURNAL :

Afandi, Dedi., "Hak Atas Kesehatan Dalam Perspektif HAM," Jurnal Ilmu Kedokteran, , Jilid 2 Nomor 1. ISSN 1978-662X, (Maret 2008).

Handayani, Rina Tri. et.al. "Pandemi Covid-19, Respon Imun Tubuh, Dan Herd Immunity," Jurnal IImiah Permas, Sekolah Tinggi IImu Kesehatan Kendal, Volume 10 No.3 (2020).

Rahmatini, "Evaluasi Khasiat Dan Keamanan Obat (Uji Klinik)," Majalah Kedokteran Andalas No.1. Vol.34. (2010).

Rahmawati, Nur Ainiyah. "Hukum Pidana Indonesia: Ultimum Remedium Atau Primum Remedium," Jurnal Recidive Vol. 2 No. 1 (Januari - April 2013).

Santoso, Bagus Teguh., Pemberian Grasi Oleh Presiden Bagi Terpidana Antasari Azhar, Mimbar Yustisia, Vol.1 No.1 (Juni 2017).

WEBSITE :

Badan Pengawas Obat dan Makanan, "Penerbitan Persetujuan Penggunaan Dalam Kondisi Darurat Atau Emergency Use Authorization (EUA) Pertama Untuk Vaksin 
Covid-19," Siaran Pers BPOM 11 Januari 2021, dikutip dari laman resmi BPOM https://www.pom.

Persetujuan-Penggunaan-Dalam-Kondisi-

go.id/new/view/more/pers/584/Penerbitan-

Darurat-Atau-Emergency-Use-Authorization-

-EUA--Pertama-Untuk-Vaksin-Covid-19.html, (diakses pada 5 Februari 2021).

Kompas TV, "Wamenkumham Luruskan Berita "Warga Tidak Mau Divaksin Bisa Masuk Penjara," dikutip dari laman Kompas TV https://www.kompas.tv/article/137625/ wamenkumham-luruskan-berita-warga-tidakmau-divaksin-bisa-masuk-penjara?page=all (diakses pada 17 Februari 2021).

Law Justice, "Natalius Pigai: Menolak Vaksin adalah Hak Asasi Rakyat!", 2021, Dikutip dari laman https://www.law-justice.co/artikel/100970/ natalius-pigai-menolak-vaksin-adalah-hak- asasi-rakyat/ (diakses pada 13 Januari 2021).

Majelis Ulama Indonesia., "Komisi Fatwa MUI Pusat Menetapkan Vaksin Covid-19 Produksi Sinovac Halal dan Suci", 2021, dikutip dari laman resmi Majelis Ulama Indonesia, https:// mui.or.id/berita/29405/komisi-fatwa-muipusat-menetapkan-vaksin-Covid-19-produksi- sinovac-halal-dan-suci/ , (diakses pada 9 Januari 2021).

Reuters, "China approves Sinovac Biotech Covid-19 vaccine for general public use", 2021, health-coronavirus-vaccine-sinovac/chinaapproves-sinovac-biotech-Covid-19-vaccinefor-general-public-use-idUSKBN2A60AY, (diakses pada 7 Februari 2021).

Sekretariat Kabinet Republik Indonesia. "Cegah Covid-19 dengan 3M, 3T, dan Vaksinasi" 2020, dikutip dari laman resmi Sekretariat Kabinet Republik Indonesia https://setkab.go.id/ gallery/cegah-Covid-19-dengan-3m-3t-dan- vaksinasi/ (diakses pada 28 Desember 2020).

Sekretariat Kabinet Republik Indonesia, "Menkes Sebut Vaksinasi Covid-19 Akan Dimulai Pekan Depan", 2021, dikutip dari laman resmi Sekretariat Kabinet Republik Indonesia, $\quad$ https://setkab.go.id/menkes-sebut-vaksinasiCovid-19-akan-dimulai-pekan-depan/ . (diakses pada 9 Januari 2021).

Sekretariat Kabinet Republik Indonesia, "Pelaksanaan Vaksinasi Covid-19 Perdana di Indonesia, 13 Januari 2021, di Istana Merdeka, Provinsi DKI Jakarta," dikutip dari laman resmi Sekretariat Kabinet Republik Indonesia, https://setkab.go.id/pelaksanaan-vaksinasi-

Covid-19-perdana-di-indonesia-13-januari-

2021-di-istana-merdeka-provinsi-dki-jakarta/

, (diakses pada 13 Januari 2021).

Sekretariat Kabinet Republik Indonesia, "Uji Klinis Selesai, BPOM: Aspek Keamanan Vaksin Sinovac Baik," 2021, dikutip dari laman resmi Sekretariat Kabinet Republik Indonesia, https://setkab.go.id/uji-klinis-selesai-bpomaspek-keamanan-vaksin-sinovac-baik/ (diakses pada 4 Februari 2021). 
Sekretariat Kabinet Republik Indonesia, "Vaksinasi Segera Dimulai, Presiden: 329,5 Juta Dosis Vaksin Covid-19 Telah Dipesan", 2021, dikutip dari laman resmi Sekretariat Kabinet Republik Indonesia, https://setkab.go.id/vaksinasi-segera-dimulai-presiden-3295-juta-dosisvaksin-Covid-19-telah-dipesan/. (diakses pada 9 Januari 2021).

\section{Peraturan Perundang-Undangan:}

Undang-Undang Dasar Negara Republik Indonesia Tahun 1945.

Undang-Undang Nomor 4 Tahun 1984 Tentang Wabah Penyakit Menular, Lembaran Negara Republik Indonesia Tahun 1984 Nomor 20, Tambahan Lembaran Negara Republik Indonesia Nomor 3273.

Undang-Undang Nomor 12 Tahun 2005 Tentang Pengesahan International Covenant On Civil And Political Rights (Kovenan Internasional Tentang Hak-Hak Sipil Dan Politik), Lembaran Negara Republik Indonesia Tahun 2005 Nomor 119, Tambahan Lembaran Negara Republik Indonesia Nomor 4558.

Undang-Undang Nomor 36 Tahun 2009 tentang Kesehatan, Lembaran Negara Republik Indonesia Tahun 2009 Nomor 144, Tambahan Lembaran Negara Republik Indonesia Nomor 5063.

Undang-Undang Nomor 6 Tahun 2018 Tentang Kekarantinaan Kesehatan Lembaran Negara Republik Indonesia Tahun 2018 Nomor 128, Tambahan Lembaran Negara Republik Indonesia Nomor 6236.

Peraturan Pemerintah Pengganti Undang-Undang Nomor 1 Tahun 2020 tentang Kebijakan Keuangan Negara dan Stabilitas Sistem Keuangan Untuk Penanganan Pandemi Corona Virus Disease 2019 (COVID- 19) dan / atau dalam Rangka Menghadapi Ancaman Yang Membahayakan Perekonomian Nasional Dan/ Atau Stabilitas Sistem Keuangan, Lembaran Negara Republik Indonesia (LNRI) Tahun 2020 Nomor 87, Tambahan Lembaran Negara Republik Indonesia (TLNRI) Nomor 6485.

Peraturan Pemerintah Nomor 21 Tahun 2020 tentang Pembatasan Sosial Berskala Besar Dalam Rangka Percepatan Penanganan Corona Virus Disease 2019 (Covid-19), Lembaran Negara Republik Indonesia (LNRI) Tahun 2020 Nomor 90, Tambahan Lembaran Negara Republik Indonesia (TLNRI) Nomor 6487.

Keputusan Presiden Nomor 11 Tahun 2020 tentang Penetapan Kedaruratan Kesehatan Masyarakat Corona Virus Disease 2019 (Covid-19).

Peraturan Daerah Provinsi Daerah Khusus Ibukota Jakarta Nomor 2 Tahun 2020 tentang Penanggulangan Covid-19 DKI Jakarta, Lembaran Daerah Provinsi Daerah Khususnya Ibukota Jakarta Tahun 2020 Nomor 201, Tambahan Lembaran Daerah Provinsi Daerah Khusus Ibukota Jakarta Nomor 2008. 
$\nabla$ Edit dengan WPS Office 